\section{MICROBIAL-VIRAL ASSOCIATION OF CERTAIN INTRACELLULAR PATHOGENS (MYCOPLASMA PNEUMONIAE AND HERPES SIMPLEX VIRUS) IN PATIENTS WITH COMMUNITY-ACQUIRED PNEUMONIA}

S.V. Brusnik, N.H. Popova, L.O. Popova

SUMMARY. We analyzed contamination data on mixed infection (Mycoplasma pneumoniae and Herpes simplex virus) in patients with community-acquired pneumonia. It was found that patients with associated infection pneumonia duration had more severe character with negative consequences.

Key words: community-acquired pneumonia, mixtinfections, Mycoplasma pneumoniae, Herpes simplex virus.

Отримано 14.03.2016 р.

\title{
ПРОГНОЗУВАННЯ БАКТЕРІЙНИХ ІНФЕКЦІЙНИХ УСКЛАДНЕНЬ У ПАЦІЕНТІВ ПРИ ТРАНСПЛАНТАЦІї ГЕМОПОЕТИЧНИХ СТОВБУРОВИХ КЛІТИН
}

Білоруський державний медичний університет, 9-а міська клінічна лікарня, м. Мінськ (Республіка Білорусь)

Представлено результати оригінального дослідження, присвяченого визначенню чинників ризику розвитку бактерійних інфрекційних ускладнень при трансплантації гемопоетичних стовбурових клітин. Авторами виконаний комплексний аналіз ефективності застосування біологічних маркерів інфекцій кровоплину (прокальцитоніну, пресепсину, С-реактівного білка) у реципієнтів гемопоетичних стовбурових клітин.

Ключові слова: трансплантація гемопоетичних стовбурових клітин, фребрильна нейтропенія, чинники ризику, біологічні маркери сепсису.

Сучасні показання до трансплантації гемопоетичних стовбурових клітин (ТГСК) включають такі захворювання: гострий лімфобластний лейкоз, гострий мієлоїдний лейкоз, хронічний мієлоїдний лейкоз, мієлодиспластичний синдром, неходжкінські лімфоми, лімфому Ходжкіна, мієломну хворобу [1]. Пригнічення імунної системи організму при хіміотерапії і кондиціонуванні при ТГСК приводить до порушень в цілому комплексі системи захисту від іноекцій [2]. Серед них відзначимо порушення фрункції фрагоцитів, ураження шкірних і слизових бар'єрів, нестачу фрункції клітинної і гуморальної ланок імунної відповіді. За даними Центру міжнародних досліджень в області трансплантації клітин крові і кісткового мозку (США) за 2010-2011 рр., серед причин летального результату при ТГСК інфекції складають 8 \% при авто-ТГСК, 12 \% - при спорідненій ало-ТГСК і 17 \% - при неспорідненій ало-ТГСК [3], причому основними збудниками інфекційних ускладнень $€$ бактерії [4-6]. Інфекційна етіологія лихоманки у пацієнтів з нейтропенією, зокрема при ТГСК, підтверджується мікробіологічно тільки в 30-50 \% випадків. Причинами даного явища $є$ різко знижена імунна відповідь (особливо відсутність запальної реакції гранулоцитів), невелика кількість збудників у досліджуваному біологічному матеріалі, а також періодична транслокація патогенів у кров через пошкоджені хіміотерапією слизові оболонки [7]. Показано, що чутливість мікробіологічного методу у даної категорії пацієнтів особливо залежить від обсягу досліджуваного біологічного матеріалу: для встановлення етіології лихоманки рекомендується забирати не менше 30 мл крові [8]. 
Повсюдне зростання множинної стійкості до антибіотиків, розповсюдження нозокоміальних патогенів значно ускладнили лікування ряду інфекційних захворювань [9]. Така тенденція торкнулася і відділень трансплантації кісткового мозку, де особливо важлива раціональна антибактерійна терапія пацієнтів після хіміотерапії, від успіху якої часто залежить життя пацієнта [10]. Враховуючи невисокий рівень і швидкість мікробіологічного виділення збудника бактерійного інфекційного ускладнення при ТГСК, найбільш авторитетні американські та європейські клінічні рекомендації засновані на ранньому призначенні емпіричної антибактерійної терапії. Проте проблема раціонального вибору режиму і схеми антибактерійної терапії залишається невирішеною [11-13]. Описаний ряд чинників, що впливають на вірогідність розвитку інфекції при ТГСК, серед яких виділяють епідеміологічні, клінічні й анамнестичні [11]. На підставі наявності певних чинників ризику у конкретного пацієнта лікар повинен вибрати ескалаційний або деескалаційний режим емпіричної антибактерійної терапії інфекції. Гетерогенність клінічних характеристик пацієнтів 3 нейтропенією при лікуванні онкогематологічних захворювань і ТГCK показана E. Velasco і соавт. Автори публікації підкреслюють важливість створення і впровадження способу розподілу даної категорії пацієнтів на групи на підставі чинників ризику для раціонального вибору режиму лікування [14]. Оскільки антибактерійна терапія пацієнтів при ТГСК призначається в основному емпірично, украй важливою 3 клінічної точки зору $є$ можливість використання біологічних маркерів сепсису для уточнення діагнозу інфекції кровотоку у пацієнтів 3 фебрильною нейтропенією без мікробіологічного підтвердження. Сьогодні в світі активно застосовуються такі біологічні маркери сепсису: С-реактивний білок, інтерлейкін-6, прокальцитонін і пресепсин. Діагностична значущість кожного з них у реципієнтів гемопоетичних стовбурових клітин і у пацієнтів після хіміотерапії вивчена мало, а наявні дослідження обмежені малим об'ємом вибірки [15].

Мета дослідження - визначити клінічні чинники ризику і оцінити ефективність лабораторних маркерів бактерійних інфекційних ускладнень при трансплантації гемопоетичних стовбурових клітин.

\section{Пацієнти і методи}

Для досягнення поставленої мети в проспективне клінічне обсерваційне дослідження були включені пацієнти, що знаходяться в листі очікування на проведення ТГСК, а також пацієнти, яким була виконана ТГСК в Республіканському центрі гематології і пересадки кісткового мозку на базі УОЗ «9-а міська клінічна лікарня» (м. Мінськ, Республіка Білорусь) у період із січня 2013 р. по вересень 2015 р.
Як критерії включення пацієнтів у дослідження використовувалися міжнародні показання до ТГСК, схвалені Європейською групою по трансплантації клітин крові і кісткового мозку [1]. Критеріями виключення з дослідження були прийняті: кахексія; серцева недостатність III-IV фрункціональних класів; тяжкі порушення ритму і провідності; нестабільна стенокардія; гострий інсраркт міокарда; тяжкі психічні порушення; супутні онкологічні захворювання; підтверджена системна вірусна або грибкова інсрекція. Група пацієнтів, включених у дослідження, була однорідна відносно статусу основного захворювання: на момент дослідження у всіх була констатована повна клініко-гематологічна ремісія. Загальна кількість включених у дослідження - 271 людина: 135 пацієнтів основної групи і 136 пацієнтів контрольної групи. Вік пацієнтів основної групи склав 18-79 років, медіана віку - 44 роки (25-75 \% - 32-53 роки), з них 71 жінка (52,6 \%), 64 чоловіки (47,4 \%). У всіх пацієнтів, включених у дослідження, проспективно реєструвалися демографрічні, клінічні і лабораторні дані в процесі підготовки і при проведенні ТГСК. Як первинний клінічний результат було вибрано наявність у пацієнта мікробіологічно підтвердженої бактерійної інсекції при відповідності критеріям фебрильної нейтропенії [12]. У контрольну групу відбиралися пацієнти, що перенесли ТГСК, а також ті, що знаходилися в процесі підготовки до ТГСК і не мали епізодів фебрильної нейтропенії або інших ознак іноекційних ускладнень. Контрольна група фрормувалася із застосуванням методу узгодження («метчинг») з основною групою по вікових характеристиках, статі, а також основних діагнозах.

Як потенційні чинники ризику розвитку бактерійних інфрекцій і фребрильної нейтропенії при ТГСК в аналіз були включені такі параметри: тип режиму хіміотерапії/ кондиціонування (мієлоаблативний, немієлоаблативний, кондиціонування при авто-ТГСК, ВХТ), тип трансплантації (автологічна, алогенна споріднена і алогенна неспоріднена), джерело гемопоетичних стовбурових клітин (периферичні ГСК або кістковомозкові ГСК), наявність препаратів для профрілактики РТПХ в схемі терапії (циклоспорин, такролімус, антитимоцитарний імуноглобулін), попередня ТГСК-химіотерапії колонізація слизових оболонок пацієнта клінічно значущими мікроорганізмами (грампозитивними або грамнегативними), тип режиму вживаної антибактерійної профрілактики або відсутність такої. Окремо виконували аналіз клінічно значущих мікроорганізмів, що колонізують слизові оболонки, потім у пацієнтів при ТГСК оцінювався вплив колонізації на ризик розвитку інфекційних ускладнень і виживаність. Матеріал для мікробіологічного дослідження забирали з трьох епітопів у кожного з пацієнтів: слизові оболонки зіву, анусу і статевих органів. До клінічно значущих колонізуючих мікроорганізмів у дослідженні були віднесені представники родини Enterobacteriaceae spp., золотистий стафрілокок, ентерококи, а також A. baumannii 
i P. aeruginosa. При цьому колонізацію даних збудників враховували в дослідженні лише при повторному виділенні мікроорганізму з одного епітопа в кількості більше $10^{5}$ КУО/мл. Виділення, первинну ідентифікацію збудника і визначення його чутливості до антибіотиків проводили в мікробіологічній лабораторії УОЗ «9-а міська клінічна лікарня» М. Мінська. У кожного з пацієнтів з феебрильною нейтропенією перед введенням антибактерійного препарату проводили забір крові по 10 мл з периферичної вени і центрального венозного катетера. Кров засівали в живильні середовища (фрлакони компанії BioMerieux (Франція) для дослідження на аеробні/анаеробні бактерії) відразу після взяття у ліжка пацієнта з дотриманням правил асептики. Флакони з кров'ю поміщали в гемокультиватор BacT/ALERT 3D компанії BioMerieux і інкубували протягом 5 діб або до отримання позитивного результату. За наявності клінічних або рентгенологічних ознак пневмонії у пацієнта медичним працівником тричі збиралася уранішня порція мокротиння. При позитивному результаті культуру відсівали на живильні середовища для подальшого дослідження. Додатково оцінювали ефективність лабораторних маркерів бактерійної індекції кровотоку у пацієнтів при ТГСК: С-реактивного білка, прокальцитоніна і пресепсина. Рівень біологічних маркерів досліджували у 52 пацієнтів основної групи, вік яких склав 18-79 років (25-75 \% - 28-51 рік). 3 них було 28 жінок (53,8 \%) і 24 чоловіки (46,2 \%). Розподіл нозологічних і трансплантаційних характеристик пацієнтів у даній досліджуваній групі відповідав основній групі в заздалегідь виконаному аналізі. У кожного з пацієнтів в наступні 24 год від початку епізоду фребрильної нейтропенії забирали кров для дослідження рівня біологічних маркерів. Потім при отриманні позитивного або негативного результату мікробіологічного дослідження пацієнта відносили в групу 3 підтвердженою бактерійною інфекцією чи ні. С-реактивний білок у сироватці крові вимірювали методом імунотурбідиметрії автоматичним біохімічним аналізатором Architect c8000 компанії Abbott Laboratories (США) за допомогою набору реагентів фрірми Dialab (Австрія). Прокальцитонін у сироватці крові вимірювали імунофрлуоресцентним методом за допомогою автоматичного аналізатора miniVIDAS/ Blue 3 набором реагентів VIDAS BRAHMS PCT компанії BioMerieux (Франція). Пресепсин вимірювали в цільній крові з додаванням ЕДТА з урахуванням значення гематокриту пацієнта імунохемілюмінесцентним методом за допомогою автоматичного аналізатора PATHFAST і набору реагентів і картріджів PATHFAST Presepsin reagent компанії Mitsubishi Chemical Medience Corporation (Японія).

Обробку і статистичний аналіз результатів здійснювали за допомогою ліцензійної версії програми MedCalc Statistical Software v.14.12.0 (MedCalc Software bvba, Ostend, Belgium). Нормальність розподілу ознаки у вибірці визначалася за допомогою тесту Шапіро-Уїлка. Результати всіх етапів визнавали статистично достовірними при значенні $\mathrm{p}<0,05$. Для категоріальних змінних застосовували методи непараметричної статистики: критерій хі-квадрат $\left(\chi^{2}\right)$, відношення шансів і точний критерій Фішера для малих вибірок. Мультиваріантний аналіз проводили методом логістичної регресії з послідовним включенням в модель змінних 3 $\mathrm{p} \leq 0,05$ у заздалегідь виконаному моноваріантному аналізі.

\section{Результати досліджень та їх обговорення}

Статистично значущі чинники ризику $(p \leq 0,05)$ за наслідками моноваріантного аналізу були включені в подальший мультиваріантний аналіз, виконаний методом логістичної регресії. Результати аналізу представлено в таблиці 1.

Таблиця 1

Результати мультиваріантного дослідження чинників ризику бактерійних інфекційних ускладнень при трансплантації гемопоетичних стовбурових клітин

\begin{tabular}{|l|c|c|}
\hline \multicolumn{1}{|c|}{ Незалежний чинник ризику } & ВШ (95 \% ДІ) & p \\
\hline Відсутність антибактерійної просрілактики фрторхінолонами & $\begin{array}{c}10,94 \\
(95 \% \text { ДІ 2,49-48,14) }\end{array}$ & 0,0016 \\
\hline Колонізація слизових оболонок грамнегативними патогенами & $\begin{array}{c}2,44 \\
(95 \% \text { ДІ 1,04-5,74) }\end{array}$ & 0,0401 \\
\hline Кондиціонування при авто-ТГСК & $\begin{array}{c}0,53 \\
(95 \% \text { ДІ 0,32-0,89) }\end{array}$ & 0,0151 \\
\hline
\end{tabular}

Таким чином, незалежними чинниками ризику розвитку бактерійних інфекційних ускладнень у пацієнтів при ТГСК є колонізація слизових оболонок грамнегативними патогенами (ВШ 2,44; 95 \% ДІ 1,04-5,74; p=0,0401) і відсутність антибактерійної профрілактики фрторхінолонами (ВШ 10,94; 95 \% ДІ 2,49-48,14; p=0,0016). Протективним чинником служить застосування режимів хіміотерапії при автологічній ТГСК (ВШ 0,53; 95 \% ДІ 0,32-0,89; $p=0,0151)$. Отже, виконавши статистичну модисрікацію даного параметра (повернення до чинника ризику), можна стверджувати, що вірогідність розвитку бактерійних інфрекцій і фебрильної нейтропенії майже в 2 рази вище у пацієнтів, що перенесли алогенну трансплантацію гемопоетичних стовбурових клітин і 


\section{ОРИГІНАЛЬНІ ДОСЛІДЖЕННЯ}

інші режими високодозової хіміотерапії (ВШ 1,89; 95 \% ДІ 1,12-3,13; $p=0,0151)$.

352 пацієнтів, включених в дослідження діагностичної чутливості і специсрічності біологічних маркерів інфекцій кровоплину, у 30 бактерійна природа лихоманки згодом була підтверджена мікробіологічними методами, у 22 збудник так і не був виділений. Межі норми C-реактивного білка варіюють від 0 до 10 мг/л, що і було взято за контрольні значення для оцінки діагностичної значущості даного показника. За наслідками проведеного дослідження описані межі норми С-реактивного білка виявилися не актуальними для пацієнтів при ТГСК, оскільки у всіх пацієнтів, включених в дослідження, незалежно від наявності або відсутності бактерійної інфрекції кровоплину рівень показника був вищий 10 мг/л стандартної норми. Такий підйом може пояснюватися вивільненням даного біологічного маркера при введенні окремих препаратів хіміотерапій, окрім цього, показник може варіювати залежно від характеристик основного гематологічного захворювання. За наслідками виконаного аналізу визначено оптимальне порогове значення (значення cut-off) концентрації C-реактивного білка у пацієнтів при ТГСК, показник склав 165 мг/л, при цьому діагностична чутливість методу була всього 40 \%, тоді як діагностична специфрічність - $91 \%$. Показник діагностичної специфрічності склав 100 \% при рівні С-реактивного білка більше 225,7 мг/л.

При дослідженні діагностичної цінності концентрації прокальцитоніну в прогнозуванні бактерійних інорекцій кровоплину як межі норми були прийняті такі діапазони:

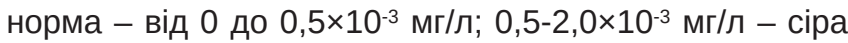
зона; вище 2,0×10-3 мг/л - вірогідна бактерійна інфекція кровоплину. Для визначення есрективності використання описаних діапазонів у пацієнтів при ТГСК був виконаний аналіз 3 використанням критерію $\chi^{2}$. Запропонований діагностичний поріг концентрації прокальцитоніну (2,0×10-3 мг/л) продемонстрував свою ефективність за наслідками аналізу у даної категорії пацієнтів (критерій $\left.\chi^{2}=7,898 ; n=38 ; p=0,0049\right)$. Показник діагностичної специфічності прокальцитоніну склав 100 \% при рівні прокальцитоніну вище $26,7 \times 10^{-3}$ мг/л.

При дослідженні діагностичної цінності пресепсину у пацієнтів при ТГСК як межі норми був прийнятий діапазон від 0 до 0,337×10-3 мг/л. Порогове значення 0,337×10-3 мг/л продемонструвало ефективність у досліджуваної категорії пацієнтів (критерій $\chi^{2}=7,406$; $n=17 ; p=0,0065)$. Результати комплексного дослідження вивчених біологічних маркерів наведено в таблиці 2.

Таблиця 2

Діагностичні показники біологічних маркерів бактерійних інфекцій кровоплину у пацієнтів при трансплантації гемопоетичних стовбурових клітин

\begin{tabular}{|c|c|c|c|}
\hline \multirow{2}{*}{ Показник } & \multicolumn{3}{|c|}{ Біологічний маркер } \\
\hline & С-реактивний білок & Прокальцитонін & Пресепсин \\
\hline Значення cut-off, мг/л & 165 & $2 \times 10^{-3}$ & $0,337 \times 10^{-3}$ \\
\hline Чутливість, \% & 40 & 62 & 75 \\
\hline Специфрічність, \% & 91 & 88 & 100 \\
\hline Площа під ROC-кривою & $\begin{array}{c}0,707 \\
\text { (95\% ДІ 0,564-0,825) }\end{array}$ & $\begin{array}{c}0,741 \\
\text { (95\% ДІ 0,573-0,869) }\end{array}$ & $\begin{array}{c}0,889 \\
(95 \% \text { ДІ 0,644-0,987) }\end{array}$ \\
\hline Станд. помилка & 0,0735 & 0,0831 & 0,085 \\
\hline $\mathrm{p}$ & 0,0049 & 0,0037 & $<0,0001$ \\
\hline Якість моделі & Добра & Добра & Дуже добра \\
\hline
\end{tabular}

Таким чином, запропоновані порогові значення концентрацій прокальцитоніна і пресепсина показали свою ефективність у цієї категорії пацієнтів. Недостатньо висока чутливість С-реактивного білка (40 \%) у пацієнтів при ТГСК може стати причиною небезпечних для пацієнтів псевдонегативних результатів.

\section{Висновки}

1. Незалежними чинниками ризику розвитку бактерійних інфекційних ускладнень у пацієнтів при ТГСК є колонізація слизових оболонок грамнегативними патоге- нами (представниками родини Enterobacteriaceae spp. A. baumannii, P. aeruginosa) і відсутність антибактерійної профрілактики орторхінолонами.

2. При автологічній ТГСК ризик розвитку бактерійних інфекційних ускладнень у пацієнтів майже в 2 рази нижче, ніж при алогенній ТГСК й інших режимах хіміотерапії.

3. У пацієнтів при трансплантації гемопоетичних стовбурових клітин оптимальна точка відсічення концентрації (значення cut-off) для C-реактивного білка 
дорівнює 165 мг/л. Визначення С-реактивного білка у даної категорії пацієнтів відрізняється малою діагностичною чутливістю (40 \%).

4. Прокальцитонін і пресепсин є статистично значущими лабораторними маркерами інфекції кровоплину у дорослих пацієнтів при ТГСК. Пороговими значеннями прокальцитоніну і пресепсину у пацієнтів при ТГСК $є$ $2 \times 10^{-3}$ мг/л і 0,337×10-3 мг/л відповідно. При порівняльному аналізі якості діагностичних моделей якнайкращий показник у пацієнтів при ТГСК показав пресепсин, потім прокальцитонін і С-реактивний білок, що дозволяє обґрунтувати оптимальний вибір лабораторного маркера інорекції кровоплину при ТГСК.

\section{Література}

1. Gratwohl A. Indications for and current practice of allogeneic and autologous HSCT / A. Gratwohl, H. Baldomero, A. Sureda // The EBMT handbook - haematopoietic stem cell transplantation / [A. Gratwohl, H. Baldomero, A. Sureda]; European Group for Blood and Marrow Transplantation \& European School of Hematology. - Paris, 2012. - P. 302-315.

2. Усс А.Л. Восстановление гемопоэза после высокодозной химиотерапии с аутологичной и аллогенной трансплантацией стволовых гемопоэтических клеток / А.Л. Усс // Мед. панорама. 2012. - № 3. - P. 48-51.

3. CIBMTR summary slides - HCT trends and survival data [Electronic resource].-2014. - Mode of access: http://www.cibmtr.org/ ReferenceCenter/SlidesReports/SummarySlides/pages/index.aspx. Data of access: 02.01.2014.

4. A prospective survey of febrile events in hematological malignancies / [L. Pagano, M. Caira, G. Rossi et al.] // Ann. Hematol. - 2012. - Vol. 91, N 5. - P. 767-774.

5. Blood stream infections in allogeneic hematopoietic stem cell transplant recipients: reemergence of Gram-negative rods and increasing antibiotic resistance / [M. Mikulska, V. Del Bono, A.M. Raiola et al.] // Biol. of Blood and Marrow Transplant. -2009. - Vol. 15, N 1. - P. 47-53.

6. Evolution, incidence, and susceptibility of bacterial bloodstream isolates from 519 bone marrow transplant patients / [B.A. Collin, H.L. Leather, J.R. Wingard et al.] // Clin. Infect. Dis. 2001. - Vol. 33, N 7. - P. 947-953.

7. Sickles E.A. Clinical presentation of infection in granulocytopenic patients / E.A. Sickles, W.H. Greene, P.H. Wiernik // Arch. Intern. Med. - 1975. - Vol. 135, N 5. - P. 715-719.

8. Bloodstream infections in neutropenic patients: early detection of pathogens and directed antimicrobial therapy due to surveillance blood cultures / [O. Penack, P. Remph, M. Eisenblatter et al.] // Ann. Oncol. - 2007. - Vol. 18, N 11. - P. 1870-1874.
9. The epidemic of antibiotic-resistant infections: a call to action for the medical community from the infectious diseases society of America / [B. Spellberg, R. Guidos, D. Gilbert et al.] // Clin. Infect. Dis. - 2008. - Vol. 46, N 2. - P. 155-164.

10. Infection prevention and control in health-care facilities in which hematopoietic cell transplant recipients are treated / [D. Yokoe, C. Casper, E. Dubberke et al.] // Bone Marrow Transplant. - 2009. Vol. 44, N 8. - P. 495-507.

11. European guidelines for empirical antibacterial therapy for febrile neutropenic patients in the era of growing resistance: summary of the 2011 4th European Conference on Infections in Leukemia / [D. Averbuch, C. Orasch, C. Cordonnier et al.] // Haematologica. 2013. - Vol. 98, N 12. - P. 1826-1835.

12. Clinical practice guideline for the use of antimicrobial agents in neutropenic patients with cancer: 2010 update by the infectious diseases society of America / [A.G. Freifeld, E.J. Bow, K.A. Sepkowitz et al.] // Clin. Infect. Dis. - 2011. - Vol. 52, N 4. - P. E56-E93.

13. Guidelines for preventing infectious complications among hematopoietic cell transplantation recipients: a global perspective / [M. Tomblyn, T. Chiller, H. Einsele et al.] // Biol. of Blood and Marrow Transplant. - 2009. - Vol. 15, N 10. - P. 1143-1238.

14. Comparative study of clinical characteristics of neutropenic and non-neutropenic adult cancer patients with bloodstream infections / [E. Velasco, R. Byington, C.A. Martins et al.] // Eur. J. Clin. Microbiol. \& Infect. Dis. - 2006. - Vol. 25, N 1. - P. 1-7.

15. Risk factor for death in hematopoietic stem cell transplantation: are biomarkers useful to foresee the prognosis in this population of patients? / [K.S. Massaro, R. Macedo, B.S. de Castro et al.] // Infection. - 2014. - Vol. 42, N 6. - P. 1023-1032.

\section{PROGNOSING BACTERIAL INFECTIOUS COMPLICATIONS IN PATIENTS RECEIVING HAEMATOPOIETIC STEM CELL TRANSPLANTATION}

\author{
I.O. Stoma, I.A. Karpov, A.L. Uss, N.F. Milanovich
}

SUMMARY. Results of original study of risk factors of bacterial infectious complications during haematopoietic stem cell transplantation are presented in this article. Authors have conducted a complex analysis of effectiveness of sepsis biomarkers (procalcitonin, presepsin, C-reactive protein) among haematopoietic stem cell transplant recipients.

Key words: haematopoietic stem cell transplantation, febrile neutropenia, risk factors, sepsis biomarkers.

Отримано 4.05.2016 р. 